Куцик В. І., к.е.н., професор

Львівський торговельно-економічний університет м. Львів, Україна

Кліпкова О. І., к.е.н.

Університет банківської справи м. Львів, Україна

DOI: https://doi.org/10.30525/978-9934-26-018-6-8

\title{
СТАН ТА ПЕРСПЕКТИВИ РОЗВИТКУ РИНКУ ЕЛЕКТРОЕНЕРГІЇ В УКРАЇНІ
}

В Україні діє єдиний Оптовий ринок електричної енергії, на якому попит формується кінцевими споживачами, задоволення якого забезпечується виробниками та імпортерами електричної енергії, а інші суб’єкти господарювання виступають як посередники між виробником та кінцевим споживачем, що обумовлено особливими споживчими якостями та фізико-технічними характеристиками товару «електрична енергія» (одночасність виробництва та споживання, неможливість складування, повернення, переадресування). Учасниками ОРЕ є:

- генеруючі компанії, або виробники електричної енергії, що здійснюють продаж виробленої електроенергії в ОРЕ (АЕС, ТЕС, ГЕС, ВДЕ);

- постачальники електричної енергії, які купують електричну енергію на ОРЕ (Обленерго, Укрзалізниця);

- ДП «Енергоринок», що здійснює функції ОРЕ;

- ДП «НЕК Укренерго», що здійснює централізоване диспетчерське (оперативно-технологічне) управління об'єднаною енергетичною системою України і передачу електричної енергії магістральними та міждержавними електричними мережами [1].

Стан енергетичного ринку, зважаючи на коливання різноманітних економічних та політичних чинників частково зумовлюватиме «Енергетична стратегія України на період до 2035 року» [2]. 
Стратегія передбачала:

- до 2020 року:

- перехід енергетичного сектору України на ринкові принципи функціонування та конкуренції, що стимулюватиме підвищення ефективності економічної діяльності суб'єктів енергетичного сектору та ефективності використання енергоресурсів суб'єктами господарювання та загалом суспільством;

- ліквідацію критичної залежності України від поставок енергоресурсів з монопольних джерел, підвищення рівня енергетичної безпеки шляхом диверсифікації маршрутів та джерел енергозабезпечення національної економіки;

- передбачає до 2025 року:

- інтеграцію енергетичного сектору України до енергетичних ринків СС та системи європейської енергетичної безпеки;

- забезпечення конкурентоспроможності національного енергетичного сектору на європейському енергетичному ринку шляхом створення сприятливих умов для залучення інвестицій та технічної модернізації об'єктів енергетичного сектору;

- до 2035 року:

- повномасштабну інтеграцію енергетичного сектору України до європейського енергетичного ринку з вільним рухом енергоресурсів, інвестицій та технологій, що забезпечить випереджаюче оновлення галузей енергетики то зростання рівня самозабезпеченості видобувними енергоресурсами;

- технологічне оновлення енергетичного сектору.

Загальним результатом реалізації Стратегії стане перетворення паливно-енергетичного комплексу країни з проблемного сектору, що потребує постійної державної підтримки, на сучасний, ефективний, конкурентоспроможний сектор національної економіки, здатний до сталого розвитку на довгострокову перспективу в умовах регіональної інтеграції та конкуренції на європейському та світовому енергетичних ринках. Функціонування ринку природного газу, незважаючи на прийняття Закону України «Про засади функціонування ринку природного газу», залишається деформованим. Збереження дисбалансу між цінами для окремих 
категорій споживачів зумовлює цілий ряд негативних наслідків. 3 одного боку, обмеження рентабельності державних компаній 3 видобування природного газу, через зобов'язання постачати газ для потреб населення за зниженими цінами, стримує зацікавленість у збільшенні обсягів внутрішнього видобутку газу державними компаніями. У свою чергу, у кризовій ситуації це зумовлює запровадження адміністративного регулювання ринку та обмежень на діяльність приватних компаній, що підриває інвестиційний клімат та довіру до Української держави. Принципами енергетичної політики України на період дії Стратегії визначаються:

- пріоритетність забезпечення сталого розвитку української економіки;

- прозорість державного регулювання енергетичного сектору, стабільність енергетичної політики та наступність управлінських рішень;

- лібералізація відносин на енергетичних ринках, недискрімінаційність ціноутворення, гарантування доступу до ринків та мереж;

- сприяння конкуренції, незалежність регуляторів енергетичних ринків, забезпечення захисту споживачів від проявів монополізму, регулювання діяльності природних монополій;

- пріоритетність інноваційного технологічного розвитку та стимулювання оновлення енергетичної інфраструктури;

- входження енергетичного сектору України в європейський енергетичний простір та європейську систему забезпечення енергетичної безпеки [3].

Для досягнення цілей Стратегії енергетичний сектор має бути послідовно трансформований 3 дотаційного, проблемного сектору в економічно прибутковий, конкурентний та мобільний сектор національної економіки. Загальний прогнозний енергетичний баланс України на період до 2035 року, з врахуванням зазначених обмежень, наведений у табл. 1.

Динаміка розвитку вугільної галузі залежатиме від успішності відновлення функціонування вугільних підприємств на основі 
модернізації технологічного обладнання та кардинального реформування взаємовідносин на ринку вугільної продукції. Основним завданням у цьому секторі $є$ переведення вугільної галузі на бездотаційний і самоокупний режим діяльності (табл. 2).

Таблиця 1

\section{Прогнозний баланс споживання}

паливно-енергетичних ресурсів на період до 2035 р.

\begin{tabular}{|l|c|c|c|c|c|}
\hline \multicolumn{1}{|c|}{$\begin{array}{c}\text { Споживання ПЕР, } \\
\text { млн. т н.е. }\end{array}$} & $\mathbf{2 0 1 3}$ & $\mathbf{2 0 2 0}$ & $\mathbf{2 0 2 5}$ & $\mathbf{2 0 3 0}$ & $\mathbf{2 0 3 5}$ \\
\hline Вугілля & 41.4 & 37.69 & 38.37 & 37.27 & 33.78 \\
\hline Природний газ & 39.5 & 37.33 & 33.57 & 33.20 & 34.17 \\
\hline Нафтопродукти & 9.85 & 13.97 & 14.86 & 15.74 & 16.48 \\
\hline Атомна енергія & 21.9 & 25.31 & 25.38 & 27.39 & 32.86 \\
\hline Біомасса, біопаливо та відходи & 1.56 & 6.38 & 8.91 & 11.85 & 13.10 \\
\hline Сонячна енергія & 0.07 & 0.37 & 0.56 & 0.70 & 0.84 \\
\hline Енергія вітру & 0.08 & 0.21 & 0.32 & 0.43 & 0.54 \\
\hline Гідравлічна енергія* & 1.14 & 0.93 & 1.02 & 1.21 & 1.25 \\
\hline Енергія довкілля & 0.05 & 0.78 & 1.42 & 1.86 & 2.40 \\
\hline Нетто експорт & & -1.03 & -1.29 & -2.15 & -2.58 \\
\hline Всього, в т.ч. & $\mathbf{1 1 5 . 5 5}$ & $\mathbf{1 2 1 . 9 2}$ & $\mathbf{1 2 3 . 1 2}$ & $\mathbf{1 2 7 . 4 9}$ & $\mathbf{1 3 2 . 8 4}$ \\
\hline не енергетичне використання & 4.93 & 4.72 & 4.96 & 5.16 & 5.31 \\
\hline Енергетичне використання & 110.62 & 117.20 & 118.17 & 122.33 & 127.53 \\
\hline у тому числі ВДЕ & 3.13 & 8.66 & 12.23 & 16.05 & 18.12 \\
\hline $\begin{array}{l}\text { Частка ВДЕ у споживанні } \\
\text { первинних ресурсів, \% }\end{array}$ & $\mathbf{2 . 7}$ & $\mathbf{7 . 4}$ & $\mathbf{1 0 . 3}$ & $\mathbf{1 3 . 1}$ & $\mathbf{1 4 . 2}$ \\
\hline $\begin{array}{l}\text { ВВП, млрд. дол. США } \\
\text { (ПКС 2005) }\end{array}$ & 391 & 457 & 540 & 638 & 761 \\
\hline $\begin{array}{l}\text { Енергоємність, } \\
\text { кг н.е./тис.дол. США }\end{array}$ & $\mathbf{0 . 3 3} * *$ & $\mathbf{0 . 2 7}$ & $\mathbf{0 . 2 3}$ & $\mathbf{0 . 2 0}$ & $\mathbf{0 . 1 7}$ \\
\hline Кінцеве споживання & $\mathbf{6 9 . 5 6}$ & $\mathbf{7 8 . 8 9}$ & $\mathbf{8 0 . 8 4}$ & $\mathbf{8 5 . 1 3}$ & $\mathbf{8 8 . 9 1}$ \\
\hline $\begin{array}{l}\text { Частка ВДЕ у валовому } \\
\text { кінцевому споживанні, \% }\end{array}$ & $\mathbf{4 . 5}$ & $\mathbf{1 1 . 0}$ & $\mathbf{1 5 . 1}$ & $\mathbf{1 8 . 9}$ & $\mathbf{2 0 . 4}$ \\
\hline
\end{tabular}

* Прогноз на 2020-2035 роки не враховує енергію отриману від ГАЕС

** Дані MEA за 2012 рік скореговані відповідно даних Держстату щодо зниження енергоємності відносно 2012 року (Енергетичний баланс України за 2013 рік) 
Цільові показники видобутку власних енергоресурсів

\begin{tabular}{|c|c|c|c|c|c|}
\hline Видобуток/виробництво & 2013 & 2020 & 2025 & 2030 & 2035 \\
\hline Природний газ, млрд. м & 21,2 & 22,9 & 27,5 & 33,8 & 42,1 \\
\hline Нафта, млн. т & 3,1 & 3,3 & 3,7 & 3,9 & 4,2 \\
\hline Вугілля, млн. т н.е. & 40,7 & 37,7 & 8750 & 41,3 & 42,8 \\
\hline
\end{tabular}

Аналізуючи поставлені орієнтири, варто враховувати, що Стратегія розроблена у 2014 році, i наслідки проведення антитерористичної операції на Сході України були ще невизначеними. Ухвалення Верховною Радою 13 квітня 2017 закону «Про ринок електроенергії» відкриває можливості для розвитку ринку, зростання конкуренції і залучення інвестицій, проте знадобиться час і професійна робота над підзаконними актами для реалізації цього потенціалу.

\section{Література:}

1. Попадченко С.А. Сучасний оптовий ринок електричної енергії i механізми регулювання в ньому. Вісник Харківського наиіонального університету сільського господарства імені Петра Василенка. 2017. Вип. 187. С. 33-36.

2. Енергетична стратегія України на період до 2035 року. Київ, 2014. URL: mpe.kmu.gov.ua/minugol/doccatalog/document?id=244979237.

3. Куцик В.І., Жихарцева О.О. Кліпкова О.І. Організаційно-економічний механізм управління діяльністю інтегрованих корпоративних систем в структурі національної економіки : монографія, Львів : Растр, 2018. 296 с. 